\title{
THE CLAY CONTENT EFFECT ON THE FORMATION OF SHALLOW MOLE DRAINAGE AND THE RATE OF LOWERING SOIL MOISTURE CONTENT
}

\author{
Siti Suharyatun ${ }^{1}$, Bambang Purwantana², Abdul Rozaq $^{2}$, Muhjidin Mawardi² \\ ${ }^{1}$ Agricultural Engineering Department, Faculty of Agriculture, Lampung University \\ Jl. Sumantri Brojonegoro 1 Bandar Lampung 35145 \\ ${ }^{2}$ Agricultural Engineering Department, Faculty of Agricultural Engineering, Gadjah Mada University, \\ Jl. Flora 1, Bulaksumur, Yogyakarta 55281 \\ Email: siti_suharyatun@yahoo.com
}

\begin{abstract}
Installing shallow mole drainage in the soil is influenced by various factors, namely; the physical properties of soil and tools which are used. One of the physical properties of soil that influences the formation of the mole drainage is the clay content of soil. This study aimed to explore the condition of the mole drainage formed in paddy soil with different clay contents. The study was conducted in a laboratory scale using a soil bin, a model of mole plough, and soil which was kept homogeneous in the boxes. The experiment was conducted at the Laboratory for Energy and Agricultural Engineering, Agricultural Engineering Department, Universitas Gadjah Mada, Yogyakarta. Mole drainage was installed in 3 paddy soils with different clay content, namely; $13.12 \%$ (soil A; loam soil), $41.17 \%$ (soil B; clay soil) and $53.36 \%$ (soil C; clay soil). The study was conducted by analyzing the geometry of the mole drainage and observing the soil deformation which occurred due to the formation of the mole drainage. The study showed that perfect mole drainages were installed in all of those three types of soil. The mole drainages were quite good and stable with little cracks. Based on the soil crack and fissuring of soil, the largest soil deformation has occurred in soil with the highest clay content and the smallest one in soil with the lowest clay content. The characteristics of those three installed mole drainages were almost the same, but they had different effect on the rate of lowering soil moisture content. Here, the mole drainage installed in loam soil is different from which of installed in clay soil. The mole drainage installed in the loam soil did not influence the rate of lowering soil moisture content. Contrary, the mole drainage installed in clay soil has effected to increase the rate of lowering soil moisture content.
\end{abstract}

Keywords: Mole drainage, soil moisture content, clay content

\section{INTRODUCTION}

Mole drains are unlined channels formed in clay subsoil by pulling a ripper blade (or leg) with a cylindrical foot (or torpedo) on the bottom through the subsoil (Hopkins, 2002). Mole drainage also means the construction of unprotected, round channels, without digging a trench, by pulling a steel lug, the mole, through the subsoil at shallow depth (Donnan et al., 1974). Christen and Spoor (1999), Bowler (1980) said that mole drain is a useful form of drainage for heavy clay soils where hydraulic conductivities are often less than 0.1 $\mathrm{m} /$ day. The primary goal of mole drainage is not to control water table which is often deep, but to eliminate surplus water from the field surface or from top soil where it may constitute "perched water table" (Kumar and Koga, 1994). Water flows into the mole drains through the cracks formed (Kusnadi, 2010).
China has developed subsurface drainage system for the rice-growing area based on research conducted in the 1950's. In the system, mole drains have been developed in various types of subsurface, covered, pipeless drains. The mole drains effectively removes excess ground and soil water. With mole drains, the groundwater table can be lowered to 40 to $60 \mathrm{~cm}$ and fields dry thoroughly and quickly for harvest, and then can be planted immediately to wheat (Soong and Wei, 1985). In addition, in his research, Kumar and Koga (1994) found that the average soil moisture in the moled plot was less than that in the control one. The lower soil moisture in the moled plot produced higher soil suction and the rate of lowering soil moisture the moled plot was much faster than that in the control. Thus, the mole drainage can be used in areas which have a problem with soil moisture in the soil and in paddy soil.

Application of mole drainage at paddy soil is purposed to increase the rate of lowering soil moisture of top soil so that 
the soil condition is suitable for the early growth of non-rice crops. In paddy soil for cultivating non-rice crops, the mole drainage is installed above hardpan layer, with puddle soil structure. Rozaq et al (1993) and Sharma et al (1986) argued that the paddy soil hardpan layer is situated in the soil with 20$40 \mathrm{~cm}$ deep, so the mole drainage should be installed in such a shallow distance which is different from usual installation in the depth of more than $60 \mathrm{~cm}$.

Mole drainage installation in distances relatively close to the ground can be risky in cultivating the soil layer above the mole. The mole drainage resistance principally depends on soil consistency and the mole depth. The mole drainage installed in soil with free water content tends to be mostly imperfect and the deeper the mole is installed, the stronger the mole's resistance is (Muller, 1988). The critical depth of mole drainage is at least 6 times deeper than the mole plough diameter (Bennet et.al.,2004). The mole plough which runs above critical depth will make soil loose but it will make soil solid if it runs below the critical depth (Godwin et al., 1981).

Some researchers have conducted researches on mole drainage for paddy soil. Among others are Rozaq (1992), Rozaq et al (1993), Purwantana (1993, 1994), Puspito (1997), and Rodger et al (2003). Soil moisture content and bulk density of the soil influence the success of installing the mole drainage in various types of soil (Rozaq, 1992). Clay content and soil moisture also has effect on the quality and stability of mole channels. Mole channels formed in soil with lower soil moisture (plastic limit) are not good; the mole channels get some failures. Mole channels formed in soil with higher soil moisture (over plastic limit) are good; the mole channels are stable with almost no failures (Purwantana, 1994). The soil with the clay content of $20 \%$ up to $50 \%$ is a good condition for installing mole drainage (Kusnadi, 2010). In other words, the mole drainage can be installed successfully enough in the soil with the clay content of $20 \%$ up to $50 \%$. Installing the mole drainage in the soil with a clay content of more than $60 \%$ is not effective, due to the excessive narrowing mole gap and in the soil with clay content less than $15 \%$ is not effective either due to the excessive failure process. So the mole drainage is not working well (Purwantana, 1993). Furthermore, the mole drainage failure is very sensitive to the effect of the bulk density and types of clay minerals (Spoor et al., 1982b).

This study aimed to explore condition of the mole drainage paddy soil with different clay content. Here, the mole is assumed will influence the increase of lowering soil moisture.

\section{METHODOLOGY}

This study is a physical-based model that is conducted in laboratory by using mole plow of soil bin (Figure 1). Soil was put into the boxes and it was maintained homogeneous. Dimensional model of mole plow and soil box is presented in Figure 2.

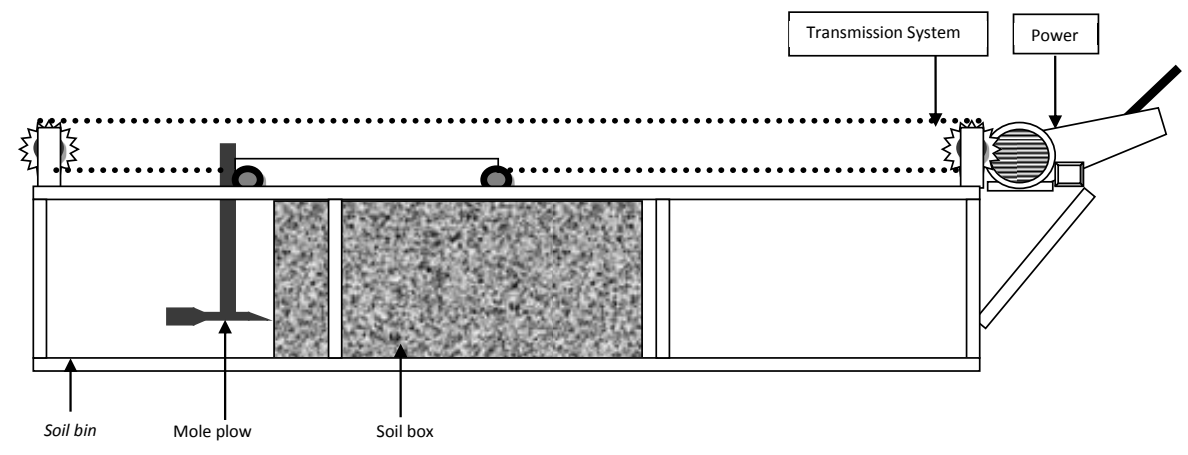

Figure 1. Schematic chart of soil bin with mole plow

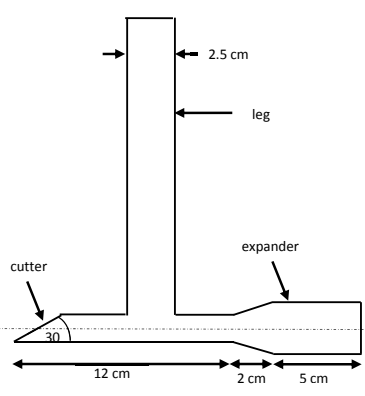

(a)

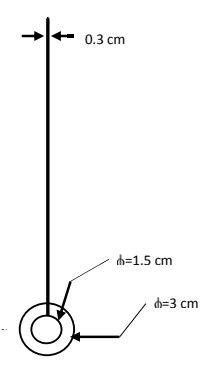

(b)

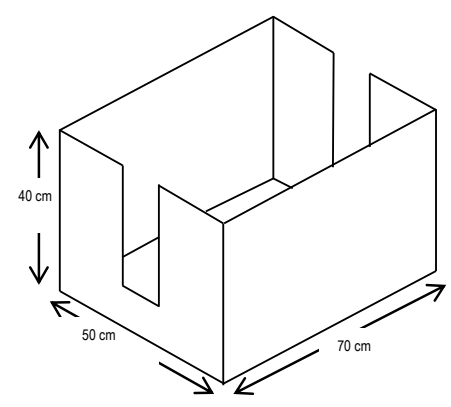

Figure 2. Dimension of mole plow (a) and soil box (b) 
The mole drainages were installed in 3 paddy soils with different clay contents. The soil taken from three different places, namely; Seyegan (soil A) and Moyudan (soil B) which belong to Godean District, Sleman Regency, and Keyongan (soil C) which belongs to Nogosari District, Boyolali Regency. Soil analysis results indicated that the soil A (clay content $13.12 \%$ ) belonged to the loam texture and that soil B (clay content $41.17 \%$ ) and C (clay content 53.63\%) belonged to clay texture. The use of loam soil and clay soil was intended to know and compare the mole drainage made in both the soil with lower and higher clay content. Each of soil type was prepared in 4 boxes; the 3 soil boxes were used to experimental study and one soil box was used as a control. Control (K) was used to identify the difference of the rate of lowering soil moisture between the moled soil and non-moled soil.

To maintain the three types of soil homogeneous, the soils had been air-dried, grinded and filtered by using standard filter with $2 \mathrm{~mm}$ in size before the three types of soil were put into the boxes. After the soils had been put in the boxes, they were watered to make them saturated approaching the real condition of those soils in real fields. The only soil saturation condition was taken because in the real field the mole drainage was made in saturated soil condition; the condition after grain harvest. This soil condition was maintained up to two months. The mole drainage was set or installed right in the middle of the box at a depth of $20 \mathrm{~cm}$ from the surface soil.

After the mole drainage was installed, the present researcher took pictures with a digital camera. The pictures were taken from the surface soil, the front and back of the box, and horizontally cutting mole. The picture of horizontally cutting mole was taken once after the formation of the mole by splitting the box into two halves (parts), while other pictures were taken periodically. The pictures were used to measure the channels' geometry and observe the soil deformation of the channels.

The parameters measured in this study were soil physical properties and the mole geometry. The soil physical properties were soil texture and soil consistency. The mole geometry were mole's diameter, mole's channel width, the gap flow passage's width, the speed of plow, plowing force and soil moisture content. To support the data, observation of forms, mole's channel split and cracks of mole was conducted. The flow chart of the study is presented in Figure 3.

Soil moisture content was measured periodically by using gypsum blocks which were planted in the soil box. The gypsum blocks were planted in the depth of $5 \mathrm{~cm}$, in the distance of $6.5 \mathrm{~cm}$ and $11.5 \mathrm{~cm}$. Each of depth and distance was set in 4 points. The gypsum blocks had been calibrated by using an electrical resistance meter before they were used for measurement. The calibration was done to read the relation between soil moisture content and soil resistance. Readings were taken by attaching an electrical resistance meter to the wire leads. Soil moisture content could be gained by reading electrical resistance of gypsum. To know the soil moisture value, the result of the readings was put into calibration equation.

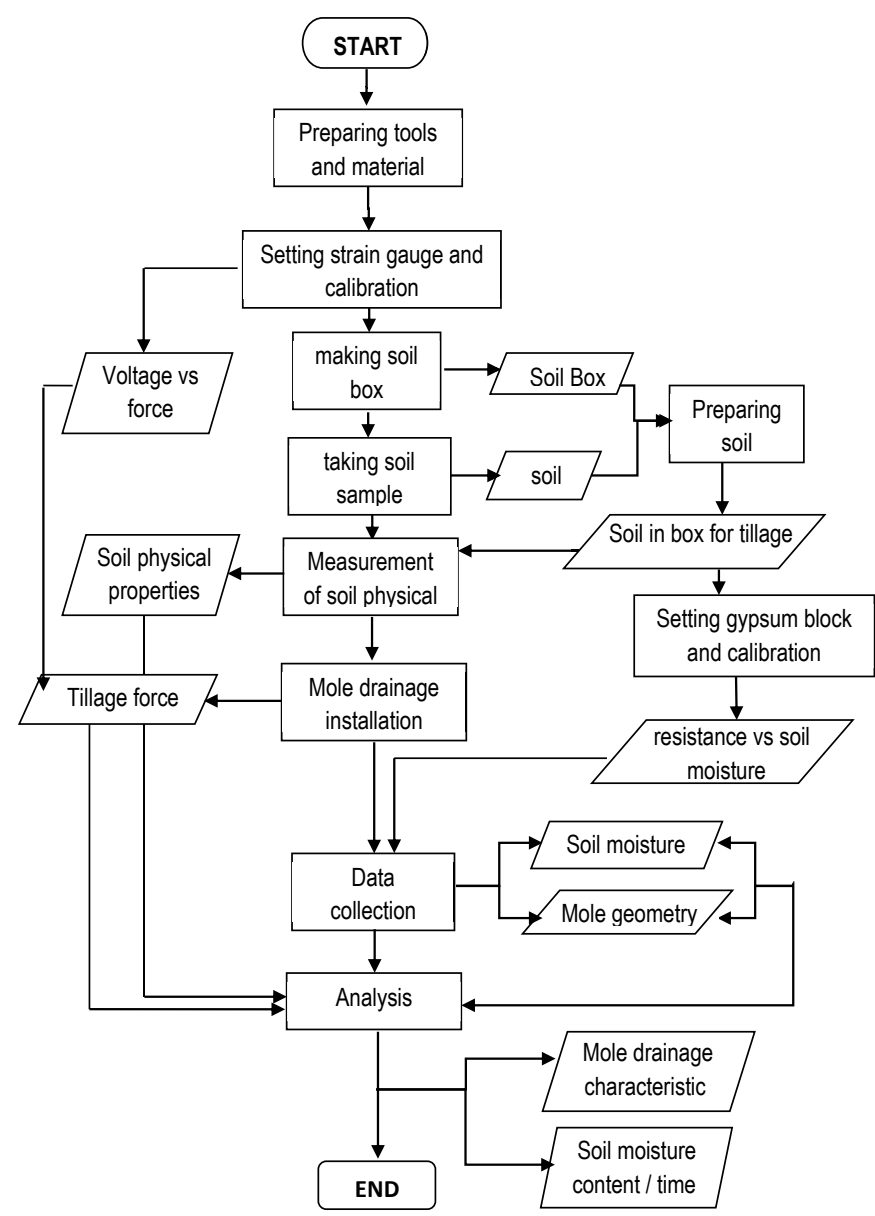

Figure 3. Flow chart of the study

\section{RESULTS AND DISCUSSION}

The mole drainage was made after the soil had been saturated for more than two months. Before the mole drainage was made in the soil, the moisture content of each of the soil types was subsequently 57.01\% (soil A), 55.48\% (soil B) and soil $\mathrm{C} 59.72 \%$. In addition, at those moisture contents, the soil water retention test results (Table 1) show that soil $\mathrm{A}$ is approaching saturated condition, while soil $\mathrm{B}$ and $\mathrm{C}$ are in saturated condition. Based on the soil consistency test results (Table 2), at those moisture contents, the soil A was in the condition above the liquid limit, while soil B and C were in the condition approaching the liquid limit. At such these moisture contents, it was expected that the good mole 
drainages could be installed. Rozaq (1992) found that mole drainage in the soil with $43.37 \%$ clay content and moisture levels approaching the limit of liquid have produced an ideal mole in term of no fractures (category A).

Table 1. Soil water retention

\begin{tabular}{cccccc}
\hline \multirow{2}{*}{ Soil } & \multicolumn{5}{c}{ Soil moisture content (\%) } \\
\cline { 2 - 6 } & sample & $\mathrm{pF} \mathrm{0}$ & $\mathrm{pF} \mathrm{2.54}$ & $\mathrm{pF} \mathrm{4.2}$ & \\
& & (field & $\begin{array}{c}\text { (permanen } \\
\text { capacity) }\end{array}$ & $\begin{array}{c}\text { (air } \\
\text { wilting point) }\end{array}$ & dried) \\
\hline A & 21.19 & 63.1 & 21.43 & 12.29 & 3.2 \\
B & 46.95 & 53.1 & 35.4 & 24.68 & 9.01 \\
C & 35.79 & 58.74 & 32.76 & 28.47 & 8.21 \\
\hline
\end{tabular}

Note: $\mathrm{pF}=\log 10$ of soil water tension

Table 3. Consistency limits of the soil

\begin{tabular}{cccc}
\hline soil code & $\begin{array}{c}\text { ll (liquid limit) } \\
\%\end{array}$ & $\begin{array}{c}\text { pl (plastic limit) } \\
\%\end{array}$ & $\begin{array}{c}\text { sl (shrinkage } \\
\text { limit) } \%\end{array}$ \\
\hline A & 39.22 & tt & 13.32 \\
B & 57.36 & 38.19 & 19.04 \\
C & 64.47 & 41.41 & 17.31 \\
\hline
\end{tabular}

Note: $\mathrm{tt}=$ immeasurable

The installation of mole drainage in the soil A, B, and $C$ produced mole drains with good geometry with a slight fracture (category B) as shown in Figure 4. The diameter and width of mole's channel of those three soil types had relatively similar value, approaching the diameter and area of plow's expander which was used (diameter $=3 \mathrm{~cm}$ and area $=$ $7.65 \mathrm{~cm}^{2}$ ). The differences could be seen in the formed flow gap. The value of the average flow gap of soil A was $0.31 \mathrm{~cm}$ approximately the same as the thickness of plow leg $(0.3 \mathrm{~cm})$, while the value of the average flow gap of soil $B$ was 0.35 $\mathrm{cm}$. Average soil C flow gap was much larger than A and B soil, worth almost three times of plow thickness, which was $0.89 \mathrm{~cm}$.

Soil conditions at the time of formation of the mole drainage would influence the soil reaction and tools which worked on it. Soil with different physical properties would react differently to the working force. It is because soil force reaction is effected by tool geometry, soil-tool friction and internal soil properties. Those properties are cohesion and internal friction angle. Using theory of Coulomb (1772), Gill and Berg (1968) said that maximum soil shearing stress depends on cohesion and internal friction angle (see Eq. 1). The cohesive soil means soil with high clay content, which has cohesive strength. The more cohesive soil is the greater the soil reaction force will be. The cohesion of soil
A $\left(c=0.0663 \mathrm{~kg} / \mathrm{cm}^{2}\right)$ was lower than soil B $(\mathrm{c}=0.0982 \mathrm{~kg} /$ $\left.\mathrm{cm}^{2}\right)$ and soil $\mathrm{C}\left(\mathrm{c}=0.1634 \mathrm{~kg} / \mathrm{cm}^{2}\right)$. The soil $\mathrm{C}$ was the most cohesive. Therefore, the highest tillage force was happening in soil $\mathrm{C}$ which had the highest clay content. Table 3 shows that although the three-mole drainage installation uses the same speed, the soil reacts differently to the working force.

$$
\tau=c+\sigma \tan \varnothing
$$

where $\tau=$ shearing stress, $\mathrm{c}=$ cohesion,$\sigma=$ normal stress and $\varnothing=$ internal friction angel.

The soil deformation in the form of cracks and fractures around the mole drainage, viewed both from the front and from the soil surface (top view), showed the differences among those mole drainages installed in the soil A, B and C (Figure 4 and 5). Figure 5 shows that the deformation, in the form of cracks and fractures, in soil $\mathrm{B}$ and $\mathrm{C}$ is greater than in soil $\mathrm{A}$ and the deformation in soil $\mathrm{C}$ is greater than soil $\mathrm{B}$. Figure 4 (c) shows that the fracture occurs in flow gap and flow gap which occurs in soil $\mathrm{C}$ is greater than the thickness of tillage foot.

Table 3. Speed of mole plow (v) and soil reaction force (F)

\begin{tabular}{ccc}
\hline soil & $\mathrm{v}\left(\mathrm{m} / \mathrm{s}^{2}\right)$ & $\mathrm{F}\left(\mathrm{kg} \mathrm{m} / \mathrm{s}^{2}\right)$ \\
\hline A & 0.05 & 142.71 \\
B & 0.05 & 169.43 \\
C & 0.05 & 222.49 \\
\hline
\end{tabular}
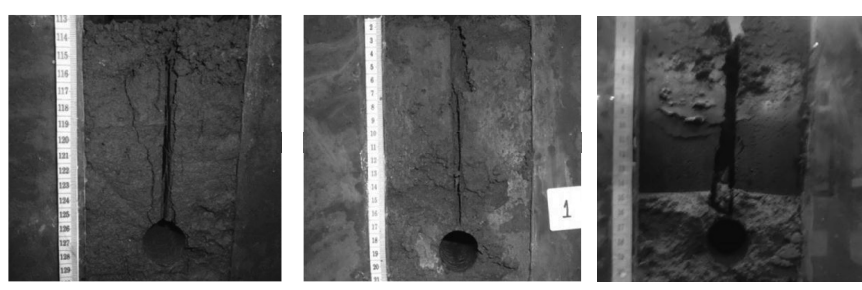

Figure 4. Front view of mole in soil A, B and C
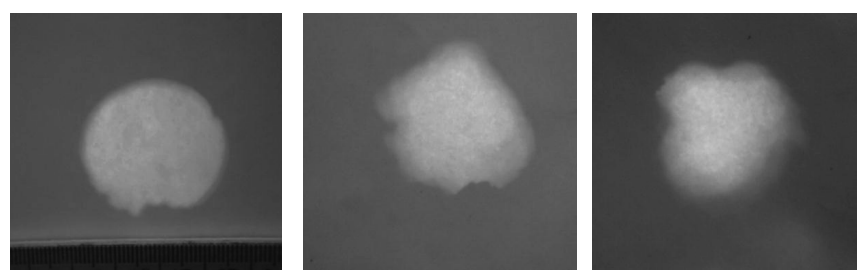

Figure 5. Top view of mole in soil A, B and C

Soil failure occurred in the mole of soil B and $\mathrm{C}$ and almost hardly occurred in soil A. In different word, there are few failures to be found in soil A. This could be seen when the LED light was turned on at the end of the mole and the shadow images were taken at the other end of the 


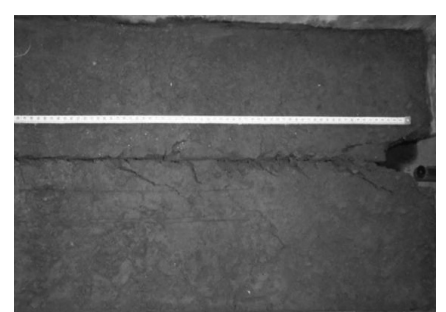

Soil A

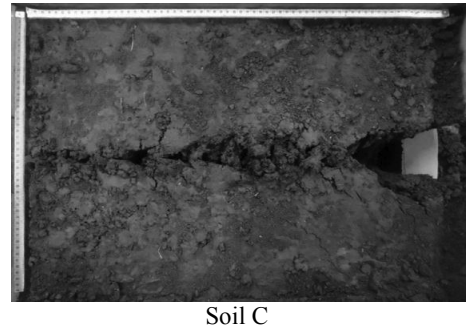

Soil B

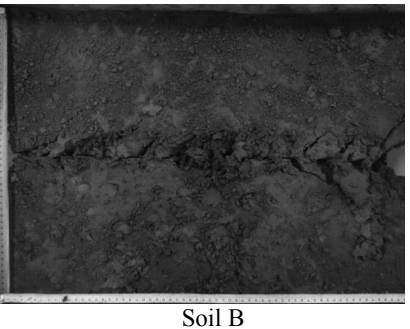

mole (Figure 4). The shadow of mole A which was almost fully round showed that almost no soil failure happened in the mole. The shadow of mole in soil B and C were not spherical but irregularly shaped. However, the failures are relatively little so that they would not influence the mole stability. This could be seen at the cutting mole (see Figure 6). Figure 6 shows that the trajectory/path of the mole plow in the soil causes the mole compaction occur around the mole walls. The walls are more solid, the mole will be more stable and able to serve longer as mole drainage. In addition, there are also cracks on the mole channel walls which necessary for increasing the rate of soil moisture movement. It has been confirmed by Leeds-Harrison et al. (1982). They say that cracks/fractures on the mole walls necessarily function to increase the rate of soil moisture movement on the mole.

This study showed that the shallow mole drainage were stable and had good geometry. Figure 7 shows that there is

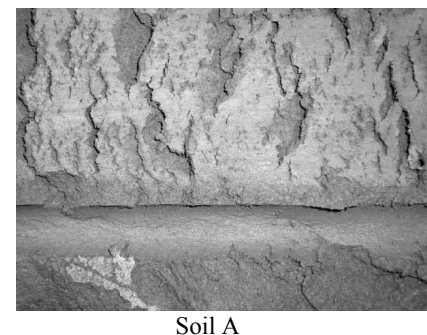

Soil A

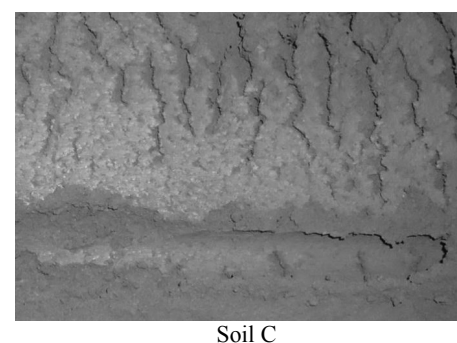

Soil C

Figure 6. Horizontally cutting mole in soil A, B, and C relatively small changing in diameter, area of mole's holes and leg slot. It has been observed during the measurement period, i.e., up to 144 hours after the formation of the mole.

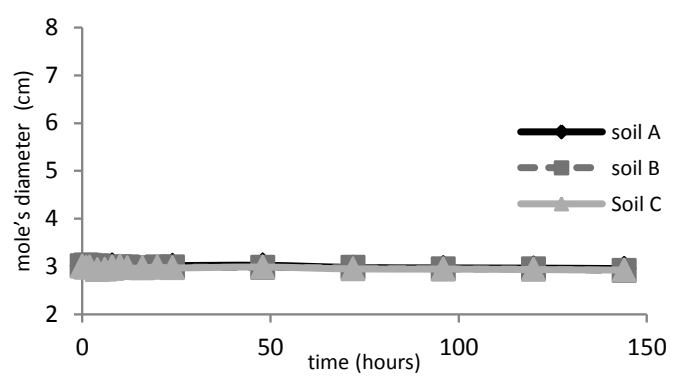

(a)

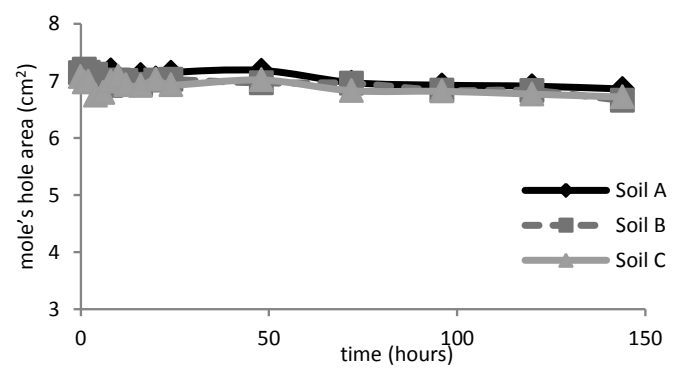

(b)

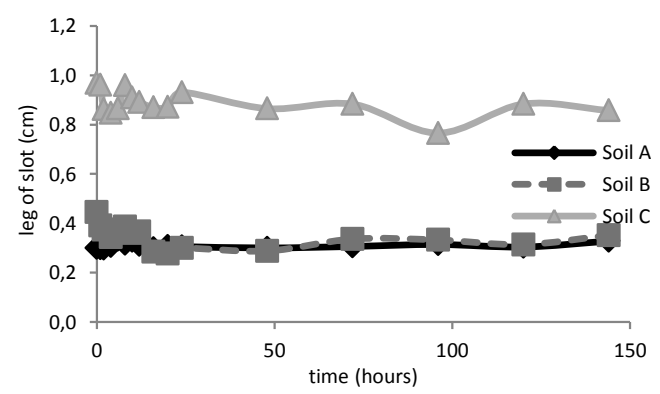

(c)

Figure 7. (a) Graph of mole's diameter, (b) Graph of mole's hole area and (c) Graph of leg slot

Although the characteristics of the installed mole drainages are almost same, but the moles functioned differently in lowering the rate of moisture content. Soil moisture content observation shows that the installed mole drainage in the soil $\mathrm{A}$ is not able to increase the rate of lowering soil moisture content. The ones which were installed in the soil B and C could increase the rate of lowering soil moisture content (Figure 8).

Figure 8 (a) shows that the chart of the increase of soil moisture movement in soil A is not in the state above the control (KA). These figures illustrate that the installed mole could not increase the soil moisture movement. The installed mole does not have any effect on the rate of soil moisture movement, because permeability of soil is found to be medium category 
( $2.82 \mathrm{~cm} /$ hour). Actually, it does not have any problem with subsurface drainage so mole drainage is not necessary for this soil type. Soil moisture movement goes rapidly enough and so does the lowering soil moisture content. On the contrary, soil $B$ and $C$ have lower permeability, $0.52 \mathrm{~cm} /$ hour and 0.05 $\mathrm{cm} /$ hour respectively. They are categorized as slow to very slow permeability.

Figure 8 (b) shows that improvement of lowering of soil moisture on soil B was found to be higher than control (KB). It means that the mole drainage could increase the rate of lowering of soil moisture. A sign improvement of soil moisture occurred shortly after installation of the mole and it happened up to 30 hours.

The increasing rate of lowering soil moisture also found in soil C. Figure 8(c) shows that the increase of lowering soil moisture soil $\mathrm{C}$ is higher than control $(\mathrm{KC})$. The high increase of lowering soil moisture occurred starting at the early installation of the mole and it continuously happened up to about 30 hours after the installation. Based on Figure 8 (b) and 8 (c), it can be concluded that the increase of lowering soil moisture in soil $\mathrm{C}$ is higher than the one in soil $\mathrm{B}$.

(a)

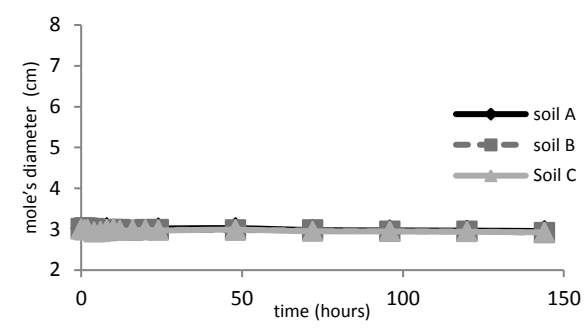

(b)

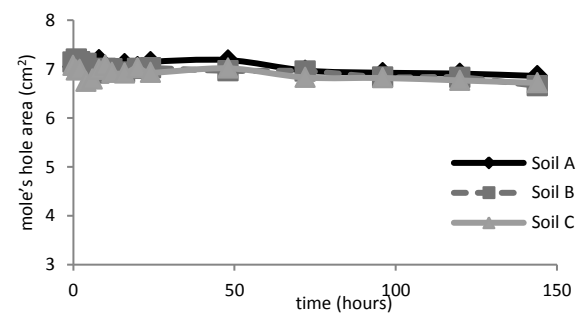

(c)

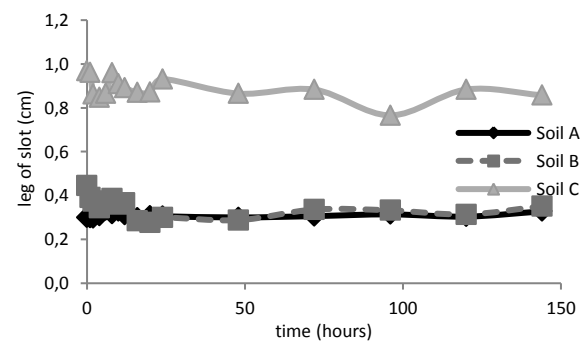

Figure 8. (a) Graph rate of lowering soil moisture content soil A, (b) Graph rate of lowering soil moisture content soil B, and (c) Graph Rate of lowering soil moisture content soil C.

\section{CONCLUSION}

1. Installation of mole drainage in the soil A (13.12\% clay content), B (41.17\% clay content), and C (53.63\% clay content) produced good moles with slight fracture (category B).

2. Higher intensity of soil deformation in the form of cracks and fractures around the mole drainage happened in soil $\mathrm{C}$ both from soil surface (top view) and the front sight. The medium intensity happened in soil B and the lowest intensity occurred in soil A.

3. Based on the visual observation and geometric measurement, mole drainage of soil $\mathrm{A}, \mathrm{B}$ and $\mathrm{C}$ were similar, good and stable.

4. The mole drainage installed in the three types of soil functioned differently. The mole drainage in the soil A did not influence the rate of lowering soil moisture content, but it increase the rate of lowering soil moisture content in soil B and C. The increase rate of lowering soil moisture content in soil $\mathrm{C}$ was greater than in soil $\mathrm{B}$.

\section{REFERENCES}

Bennet, D., Richard, G. and Bill, R. (2004). Mole Drainage for Increased Productivity in The South West Irrigation Area. State University of Western Australia.

Bowler, D.G. (1980). The Drainage of Wet Soils. Hodder and Stougton. Auckland, New Zealand.

Christen, E.W. and Spoor, G. (1999). Improving controlling irrigation water flow to mole drains. Journals of Irrigation and Drainage Engineering 125: 59-63.

Gill, W. R. and Berg, G.E.V. (1968). Soil Dynamics in Tillage and Traction. Agricultural Hand Book. United States Department Agricultural.

Godwin, R.J., Spoor, G. and Leeds-Harrison, P. (1981). An experimental investigation into the force mechanics and resulting soil disturbance of mole plough. Journal of Agricultural Engineering Research 26: 477-497.

Hopkins (2002). Installation of mole drainage by mole plow with floating beam. http://www.tgdrains.com.au/page5. htm. [2 Oktober 2014].

Kumar, M.J. and Koga, K. (1995). Mole drainage: prospective drainage solution to Bangkok clay soils. Journals of Agricultural Water Management 28: 253-270.

Kusnadi, K.D. (2010). Teknik Drainase Bawah Permukaan. Graha Ilmu, Yogyakarta. 
Leeds-Harrison, P., Spoor, G. and Godwin, R.J. (1982). Water flow to mole drain. Journal of Agricultural Engineering Research 27: 81-91.

Muller, L. (1988). Efficiency of subsoiling and subsurface drainage in heavy alluvial soils of the GDR. Journal of Soil and Tillage Research 12: 121-134.

Purwantana, B. (1993). Rancang Bangun Kaki Bajak Lorong dan Pengaruhnya terhadap Laju Pengatusan Lengas Tanah. Research Institute. Universitas Gadjah Mada, Yogyakarta.

Purwantana, B. (1994). Pengaruh Kandungan Lempung terhadap Stabilitas Lorong Pengatus Air Tanah. Research Institute. Universitas Gadjah Mada, Yogyakarta.

Puspito, J. (1997). Identifikasi Parameter Rancang Bangun Bajak Lorong untuk Memprediksi Kebutuhan Daya Penarikan Bajak. Tesis. Fakultas Teknologi Pertanian. Universitas Gadjah Mada, Yogyakarta.

Raadsma S. (1974). Current Draining Practices in Flat Areas of Humid Regions in Europe. Drainage for Agricultural. American Society of Agronomy Inc. Wisconsin.

Rodgers, M., Mulqueen, J. and McHale, J. (2003). A model study of mole drain spacing and performance. Journal of Agricultural Management 60: 33-42.
Rozaq, A. (1992). Identifikasi Pola Patahan Tanah pada Pembuatan Lorong Pengatus Air Tanah di Lahan Sawah. Research Institute. Universitas Gadjah Mada, Yogyakarta.

Rozaq, A., Handoyo, R., Purwantana, B. (1993). Rancang Bangun Alat Pengatus Air Tanah untuk Mempercepat Penanaman Palawija di Lahan Sawah. Research Institute. Universitas Gadjah Mada, Yogyakarta.

Sharma, P.K. and De Datta, S.K. (1986). Physical properties and process of puddled rice soil. Journal of Soil Science 5: 139-178.

Soong Si-Tu and Wei Zhang. (1985). Subsurface drainage in lowland rice field in china. In: Soil Physics and Rice: 351-366. International Rice Research Institute. Los Banos.

Spoor, G. Leed-Harrison, P.B. and Godwin, R.J. (1982). Potential role of soil density and clay mineralogy in assessing the suitability of soils for mole drainage. Journal of Soil Science 33: 427-441. 